against the affected part like a feather." This is a most important point. If it he used too stroag it seems to do harm, as there is almost certain to be an attack of pain where the douche is improperly used in this way. After the baths the patient had to lie down in hed for half au hour.

Of course, this treatment is not adapted to nll cases, nor can it cure a condition that can he relieved hy surgical mensures aloae. This author's experience has shown him that the treatment at Plombieres is very successful in cases of chronic diarrhea, in constipation (though at first sight this may seem peculiar), in mucous colitis, and in appeadicitis. The baths-and the treatment is practically limited to haths, though some people drink a small quastity of water before lunch and dinaer-are recommended for various other conditions, especially for rheumatism.

\title{
PEDIATRIOS.
}

\section{DNDER THE CHARGE OF}

IOUIS STARR, M.D., OP PHILADESHL.

AxD

\section{THOMIPSON S. WESTCOTT, MI.D.,} OP PTILEDLPDIS.

A Case of Pneumothorax Complicating Whooping-Cough.-Fraxcis VILLY (The Afedical Chronicle, MIay, 1900, p. 99) reports a case of this rare complication of pertussis. The patieut was a boy, aged three years, who was admitted to the hospital suffering from a severe attack of faucial diphtheria complicating whooping cough, and convalescing from measles which lasd begun nine days heforc, and was accompanied by otitis media. The faucinl condition cleared up rapidly, but meanwhile the attacls of coughing, which were slight and infrequent at first, hecame very numerous aad severe. From the begianiag the pulse rate had heen rapid, as is often observed in those who suffer from diphtheria and whooping-cough together. The rate of respiration was also increased, hnt no nhnormal physical sigas were to be fousd is the Iungs, nor in the heart beyond a shorteniag of the first souad. Definite ahaormal physical signs were found in the lungs for the first time three weeks after admission to the hospital, in the form of riles heard all over hoth luags, but especially at the bases; several small areas of rather doubtfully impaired resonance were noted. When first seen by the reporter, a week later, the child was exceedingly ill. The pulse was rapid, regular and full, but of very low tension, 145 to the minute. Paroxysms were frequent and very severe, and in the isterval respiration was shallow and rapid, averaging 80 to the misute. Several small patches of hronchopneumonia were noted at the hases posteriorly. By the next day riles had hecome very marked at the left hase, while jnst helow and internal to the angle of the scapula the breath-souads were distant, and the expiratory murmur was pro- 
longed and almost broaehial in type, hnt nn dalness was observahle. Oa the following day sliglit hyper-resonance was detected over the left hase. The needle of an exploring syriage was inserted helow the angle of the left scapula and gave issue to gas, which readily filled the syringe. Two days later aspira. tiou was made under chloroform, with the iden of evacuating the gas and pus. if the latter were present, sinee the temperature had remained slightly and irregularly elevated since admission to the hospital. A considerahle quantity of gas was evacunted, hut no pus aecompanied it. On the following day the differenees in the physical signg at the tro hases had disappeared, and steady improvement in the child's eondition continued, the whoopiag-cough progressing slowly to ultimate reeovery.

The Treatment of Whooping-Cough with Antitussin.-MAxHeIx (Berliner llinische Wochenechrift, Decemher, 1899) reports his experieace in the treatment of pertussis with this receatly introduced remedy. Antitussin is a preparation containing five parts of difluor-diphenyl, ten parts of vaseline, and eighty-five parts of lanolia. It is used by inunction, a portion of the ointment as large as a walnut heiag rubbed into the skia three or four times a day. The writer reports sisteen cases in which this preparation was used with most gratifying results, nine of tho cases heing in the convulsive stage when treatmeat was hegun. His conclusions are that antitussin has a marked anti-convulsive action in every case, and that the characteristic attacks are much lessened is severity, and the eonvulsive stage soon changes to the catarrhal; that it has a murked expectornnt action, so that the tenacious mucus is eusily expectorated : that when treated with antilussin at the oaset, or shortly after, the disease will not pass heyond the catarrhal stage; that thero is no torie effect. The drug has been used in catarrhal diseases of the larynx and bronchi aad bas shown a inarked expectorant action.

Panaris Due to the Diphtheria Bacillns,-Seirz (Correxpondenz-Blall $f$. schtceiz. Aert., 1899, No. 21) relates a curious observation under this title. He had occasion to treat a boy, aged sixteea years, for a small superficial panaris of the right middle finger, which healed rapidy after opening. Bacteriological examination of the pus showed the presence of streptocoeci, staphylococei, and an organism which at first was taken for a pseudo-diphtheria haecillus, but whieh was recognized, nfer iaoculation experiments, as a true diphtherin hacillus suffieiently virulent to kill guinea-pigs in from two to three days. When this fact was estahlished a culture was made from the throat of the paticnt, five weeks anter the opening of the ahscess on the finger, nnd virulent Klebs-Loffier hacilli were fouad. The hoy stated that he was ia the hahit of hiting his finger nails.

At the anme time other members of the patient's family werc examined; the throats of the father, the mothcr and a sister were free from the organism. But it appeared that a brother separated from the family for three months, and never having heen in coatact with the patient during this period, had had diphtheria ahout one moath after the patient's panaris developed. The patient had therefore carried viruleat hacilli in his throat without having diphtheritic angina and without infecting other memhers of his family.

Several other instances of diphtheritic panaris nre related by Hav (Lyon 
Sfedical, 1900, No. 4), one in his nwn person as the result of infection during an autopsy upon a child dead of diphtherial croup. Two other enses were ohserved in the same bospital alout this time nnong the nurses, the location in both instances being on the palmnr surfnce of the ungual phalnnx of the thumb. All three cases were chnracterized by the alsence of false membrane and by the presence of a sero-purulent liquid rich in bacilli. Tue acute stage was short and the general renetion sligbt. Constitutional treatment was not employed. Disappearance nf the bacilli was not obtained until the surface of the lesion was exposed to light and air.

Treatment of Thrush-Eschericu (SEmaine Médical, 1900, in Revue Ifensuelle des Mfaladies de I'Enfance, June, 1900, p. 304) makes use of an ingenious dcvice for the treatment of myeotic stomatitis. He directs that a small tampon of sterile cotton be impregnated with nbout 20 centigrammes of horic acid finely pulverized nnd mixed with it small quantity of sacebarine. The cotton is then enclosed in a little sne of silk or batiste carefully sterilized, and this is given to the infant to suek. Ordinarily the ehild will continuc to suck it on aceount of the stret taste imparted by the saccharine. The horic acid is thus slowly dissolved by the saliva and acts direetly and continuously upon the oidium nlbicans. A fresli sac is to be used on the following day.

The effect of this treatment is said to be rapidly manifest. In recent cases, when the deposit is not very extensive, it disnppears entirely witbin trenty-four lours, except in the gingivo-buccul suleus, from whieb it is removed during the next twenty-four bours. In the inveterate cases cure requires a sonewbat longer time, but may be hastened by mecbanienl cleansing and lavage of the moutb witb appropriate washes.

This method of treatment is not of value in moribund cases in wbich the powrer of sucking is lost and the saliva is not secreted.

The Treatment of the Laryngitis of Measles.-Sevestre (Sociele ic Pédialrie, Séance, April 9, 1900) prefers intubation to tracheotomy when operative interference is necessary. In 1898 and 1899 he operated upon 40 cases of laryngitis of mensles complicated by diphtheria. Intubation gave 20 recoveries out of 34 cases, while all of tbree cascs subunitted to tracbcotony died, and of 3 cases subjected to tracheotomy after intubation al] recovered.

In the uncomplicated laryngitis of measles tbe results ure had for nll forms of intervention. In 10 intubations Sevestre bad 8 deatbs, in 2 tracheotomies 2 deaths, and in 2 intubations followed by tracheotomy 1 death.

Ulceration of the inucosa, which is the clicf disadrnntage of intubation, cau be aroided, in a certain mcasure, by not leaving the tube long in place nnd by employing tubes of small calibre. Intubation has the advantagc over tracbeotomy of exposing less to secondary infection. Expectant treatinent should be faitbfully tried before deciding upon surgical intervention.

Chronic Vomiting Dne to Rhinopharyngitis and Adenoid Vegetations.-Breton (Revue Mlensuelle des Mraladies de I Enfance, Mny, 1900, p. 235) reports the case of a child, of five years of age, in wbom almost uncou- 
trolluble romiting appeared to he directly due to nasopharyngitis and adenoids. Vomitiug had hegun about a ycar before ohservation, at first occasiunally, hut finally it had occhrred after almost every meal. Shortly after food was taken into the stomach it would he rcjected nore or less completely. As a result of this continued loss of nourishment, scrious impairment of health followed.

Examination of the digestive organs revcaled a dilatation of the stomach and cacum, and of the transverse colon. The stools contained mucus, were lard and rcquired solicitation, heing passed with considerahle discomfort.

The tonsils were somewhat cnlarged and adenoid vegetations were studded over the wall of the pharynx, and cxtended in to the nusopharynx, while the nose was the scat of a douhlc rhinitis.

After removal of the adenoids and treatment of the nose the romiting ccased completely and the general condition of liealth at once improved. A return of vomiting was found to coincide with a relapse of tbe nusopharyngitis, and after this was successfully trented the vomiting again ceased.

Scarification versus Denudation hy Caustic Potash as a Means of Preparing the Skin for Vaccination.-Fiel,der (Mfelical Record, vol. lvii., No. 4) criticiscs the eflicacy of the method of preparing the skin for vaccinstion which was proposed ly Butchin. This is necomplished hy denuding an area of the skin hy means of liquor potassae or the stick of caustic potash. After a series of experiments in which primary raccinations were mado hoth hy scarification and by denudation, he concludes that scarification is tho more sutisfactory method. Denudation hy caustic potash is less painful to the clild and does not draw hlood, hut it takes a longer time, requires more skill, presents difficulties in getting the denuded surface small enough, so as to prevent the formation of too large a vesicle, end it is less certain than scarification, hecausc of the formation of an eschar whieh interferes with ahsorption.

Fotal Rickets,-FeDe and Cacsce (Pediatria, Fehruary, 1900) discuss in considerable detail the literature upon this much-disputed question, which dates from the description of the condition given by Glisson in the seventcenth century. Since then numerous tases bave lieen recorded as examples of fotal rickets. Certain ohservers, like Rednar, Kassowitz, Schwarz, Cohn, Quisling and Lentz, have maintaincd that such a condition as foetal rickets is of frequent occurrence, while another group claim that it is quite rare, or cven does not exist, the cases so described bcing in reality non-rbachitic in nature.

The writers have therefore undertaken n systematic study of the external characteristics of new-born infants, with carefnl bistological study of the hones of normal and of so.enlled fotul rhachitic cases.

This study cmbraced 500 new-horn infants ohserred in the maternity of the Hospital for Incurahles in Naples. In each case measurements of the length of the body, of the circumference of the liead and thorax, of the fronto-occipital arc, and of the biparietal nre were recorded.

Of tlie 500 in fants studied, 474 were horn nt term, 22 at 8 months, 4 at 7 months. Of the full-term infants 248 were males and 226 females; of the 
22 born at 8 months, 12 were boys and 10 girls, while of the 4 born at 7 months 2 wcre hoys and 2 girls.

Craniotabes was present in 3 cases ont of the 474 born at tern, and in 1 of the 22 horn at the end of the eighth month of gestation. Only onc casc in the $\mathbf{5 0 0}$ conld he said to have the elinical signs of rhachitis. The authors therefore conclude that since only 1 case in 500 showed distinct signs of rhachitis, and only 4 had craniotahes as the sole rhachitic sign, fotal rickets must he a very rare affection.

\title{
THERAPETICS.
}

\section{UNDEE THE CHARGE OP}

\begin{abstract}
REYNOLD W. WILCOX, M.D., LL.D.,

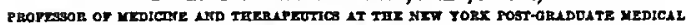

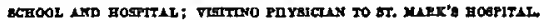

Resaldol-DR. BERmur $\triangle N$ states that this is a condensation product of resorcin with saloform, the latter in turn heing chlormethylene salicylic acid. It occurs as an amorphous, gellow, light powder. which is soluhle in water, in the usual weakly acid solutions, hut more readily soluhle in diluted soda. and particularly in alkaline solutions. Theoretically, on breaking up, it should exhihit the antiseptic properties of salicylic acid with the astringeat effects of resorcin, and since it is soluhle only in alkalies these eftects should he exhihited chiefly in the intestines. The poxder is of an astringent taste. Because it is rather difficult to swallow, capsules or wafers ure prepared for its admia istration. The remedy is relatively harmless, for a daily amount of 150 grains prodnces no untoward symptoms. It seems to he effective when given hy ea ema in amount of fifteen to thirty grains in six onnces of harley water. Since it is not without some infuence upon hacteria, the results of its administration to a patient suffering from chemico-infectious diarrhoes is of interest. Three patients sufering from intestiual tahcrculosis received henefit. On the other hand, in typhoid fever the results were not positive. The intestinal catarrh of children and chronic catarrh of the large intestine in adults yield to the remedy. For the former thrce five-grain doses are given daily; for the latter, shout fifteen grains thrice daily.-Therapeutische Afonatshefle, 1900, Heft 4, S. 199.

Ichthoform-Drs. S. RABON and B. GALLI-VALERIo lave studicd this substance, which is a combination of ichthyol and formaldehyde. Experimentally it is shown to hinder the development of hacterium coli, hacillus typhosns, hacillus icteroides, hacillus pyocyaneus and staphylococcus pyogenes aurens. It is in small quantities an active deodorant; and is, so far as evidence is afforded hy frogs and guinen-pigs, non toxic. As an internal antiseptic, thirty to forty-five grains hare hcen administered for several days at a time in various intestinal diseases, with good results; no unpleasant symp- 